\title{
The spirit of a place: materiality, spatiality, and feeling in Afro-American religions
}

\section{Katerina Kerestetzi}

Translator. Dominic Horsfall

\section{OpenEdition}

\section{Journals}

Electronic version

URL: https://journals.openedition.org/jsa/15573

DOl: 10.4000/jsa. 15573

ISSN: 1957-7842

This article is a translation of:

L'esprit du lieu : matérialités, spatialités et ressenti dans les religions afro-américaines - URL : https:// journals.openedition.org/jsa/15561 [fr]

Publisher

Société des américanistes

\section{Printed version}

Date of publication: 15 June 2018

ISSN: 0037-9174

\section{Electronic reference}

Katerina Kerestetzi, "The spirit of a place: materiality, spatiality, and feeling in Afro-American religions", Journal de la Société des américanistes [Online], 104-1 | 2018, Online since 15 June 2018, connection on 02 September 2022. URL: http://journals.openedition.org/jsa/15573 ; DOI: https:// doi.org/10.4000/jsa. 15573 


\title{
The spirit of a place: materiality, spatiality, and feeling in Afro-American religions
}

\author{
Translation from French by Dominic HorsfaLl \\ Katerina KeRESTETZI *
}

Sacrality is, above all, a category of emplacement.

Jonathan Smith, 1987, p. 104

We necessarily express ourselves by means of words, and we usually think in terms of space.

Henri Bergson, 1889, p. 7

What if instead of asking "What do you believe in?," we asked "Where do you believe?" And what if we supposed that religious places do not in fact derive from belief, but that belief derives from place? This is the premise of the line of thought taken in this volume, in which each article explores how place or setting can influence religious practices, representations, and emotions. By religious places, we are referring to sanctuaries, temples, or churches, that is, any location designed to accommodate devotees of a given religion. Yet we also ascribe a broader meaning to the term, viewing a religious setting as a locus whose "material affordances" (Gibson 1977) facilitate encounters between different entities separated in space, in time, or even ontologically; like a bond, a fundamental requirement for communication with the other world; an "operator of connection," as we might call it. In Haitian Voodoo, an altar can "happen" on a tabletop, in a bottle, or even beneath the skin of a practitioner

*CNRS, Laboratoire d'anthropologie sociale [katerina.kerestetzi@college-de-france.fr].

1. Though we might also call it an "operator of reduction" in the sense used by Bruno Latour (2007, p. 40), referring to the material devices that enable humans to interact functionally, by creating physical or mental spaces that isolate and protect their interaction from the encroachment of their social environment (like a wall that shields a conversation from indiscreet glances). Although our own approach focuses more on how space connects rather than isolates, it aligns on the notion of "framing" (as Goffman defines it) as essential for understanding the mechanisms of interaction. 
(Brown 1996, p. 67). In Palo Monte or in Cuban Spiritism, a tree that houses a deity can become the centre of a ritual, as can a mirror became the surface of a spiritual encounter (Palmié 2002, p. 2). A religious setting can also take a dematerialized form. Some studies on the transnationalization of Santería highlight the importance of digital communication devices in the endurance of this practice among the diaspora. And "digital" is not to say "disembodied": some authors point out the importance of the stimulation of electro-receptors when using these devices (Beliso-De Jesús 2015). Going further, a religious setting can also be defined by auditory space, like the one created by the cassette-letters that Haitian emigrants use to communicate with their relatives back home, which project their own sensory effect within transnational Voodoo formations (Richman 2005, p. 215).

This volume follows a pragmatic line of thinking that emphasizes the material and corporal nature of the religious, namely the objects and substances brought into play during ritual activities, the techniques of the body in worship, and religious sensoriality. ${ }^{2}$ This approach in religious anthropology sets aside the study of myth, doctrine, and symbolism in favor of the pragmatic foundations of religious practice, that is, how it is lived and experienced from both a concrete and sensory perspective (see also Cohen et al. 2017). Such an approach raises a number of important epistemological questions: should one, for example, consider the material and corporal expressions of religion as "mediations" (see Meyer 2009)? Some authors are reluctant to use this term, arguing that it is rooted in Christian-centric dualist thinking that ultimately preserves the distance and moral hierarchy between the transcendentalism of faith and the secular manifestations of the religious (see, e.g., Morgan 2013). By defining a religious setting as a coherent space in which objects, bodies, actions, and ideas form a system - or even an ecosystem - we can dispense with the dualism of this back-and-forth between faith and matter. No longer should we seek to isolate representation, action, sensation, corporeity, and materiality from the whole picture, but rather to consider them systematically and procedurally.

Religious experience is situational: it does not simply occur in any given setting; rather it derives from the specific nature of that setting (see also Richardson 2003, p. 77). Edward Twitchell Hall's (1966) theory of proxemics (i.e. the mechanisms of interpersonal distancing between humans) provides some useful methodological tools for analyzing religious experiences in their physical context, both macroscopically - the author adopts a culturalist perspective - and microscopically, essentially sensorially - the author refers to "extensions of the organism," like a computer (thus anticipating the trend of

2. See, for example, Pinney 2004; Keanne 2008; Meyer 2009; Morgan 2010; Lemonnier 2012; Stolow 2012; Espírito Santo and Tassi 2013; Promey 2014. For an overview of religious "material" approaches, see Cohen and Mottier 2016. 
extended cognition). Hall argues that our physical environments are the material manifestations of sensory patterns formed by our cultures through a filtering mechanism that develops certain senses to the detriment of others. He seeks to demonstrate how people from different cultures inhabit different sensory worlds, made up of acoustic, olfactory, auditory, or thermal spaces; some authors today refer to "smellscapes" and "soundscapes" (Porteous 1990; Hirschkind 2006; Rowlands 2007). Inspired by this perspective, we could designate the framespaces of interactions with invisible beings (Goffman 1991) as an "extended sensorium" of various -scapes: of feelings (Morgan 2010, p. 57), of mood (Johnson, in this volume), of affects (Halloy, in this volume), or of perceptions (Wirtz, Kerestetzi, in this volume). Indeed, sensation, feelings, and religious experience in general are all seen here as being distributed among (Gell 1998; Hutchins 2001) and externalized in the operators of connection with the other world, in their configuration and aesthetics.

Any belief-system conditions, to variable extents, a certain way of perceiving one's environment. This is particularly true of Afro-American religions, some of which have explicit spatial prescriptions by which their members are encouraged to abide. In Cuban Santería, for example, initiates are ascribed an oracular category (oddun), meant to represent a synthesis of their own personal characteristics, fragilities, and fates. Among the recommendations of the oddun, many relate to spatial prohibitions: not standing at the center of a group of people; not crossing through the middle of a park; not stopping in the middle of a crossroads; not walking along a railway line; some even discourage people from visiting hospitals or cemeteries. These spatial prescriptions correspond to how an Afro-American deity relates to a particular space. In Brazilian Candomblé, for example, Yemanjá is mistress of the sea, Oxun is associated with rivers and waterfalls, Exu presides over crossroads, etc. And so worshippers develop a specific, ritualized relationship with the place of the deity with whom they are associated. Thus, for the "sons" and "daughters" (filho, filha) of Yemanjá, beaches are instinctively religious places where people come to lay offerings or even meditate. The mere fact of walking along a beach carries with it a sense of ritual convention. Consequently, a given place may be loaded with religious significance for one practitioner, while meaning little to another.

The importance of location in Afro-American religions is also tied to their relative lack of institutionalization and normalization. These are procedural religions structured by and through the act of fabrication and creative consumption ("consumption" in the sense of de Certeau [1980], i.e. the appropriation and accommodation of religious items by practitioners); they center on performance rather than on a formalized liturgy (Atkinson 1989), and are distinguished by the considerable variability of their practices. In the absence of normalized ritual protocols, the form of rituality and its transmission is conditioned by the tangible supports of culture, by their objects, and the aesthetic of their 
material environment. The configuration of ritual objects, the specific nature of the materials used, and the aesthetic of liturgical spaces engender religious information, movement, and cognition.

The aim of this issue is to show that material processes and their sensory effects cannot be considered without first taking into account the setting in which they occur, and which legitimizes them and orders them - the configuration of space gives order to the experience, and constrains interpretation, perception, and feeling (Cummins and Rappaport 1998). The relationship between spatiality and materiality is so organic that a religious object can acquire a completely new meaning depending on how and where it is placed, and the context in which it is used. Paul C. Johnson's article provides an ethnohistorical perspective of how the simple transposition in space of the icon of a Brazilian saint (Slave Anastácia) evokes extraordinarily contrasting representations: a symbol of black resistance; a ritual instrument for personal gain; the patron saint of a favela; or even a fashion icon or TV star. In this regard, we may refer to a situated materiality, to a sensoriality derived from context, and to a "framed interaction" (Latour 2007, p. 39) with invisible entities. The articles in this volume explore the emergence of significant religious places that are capable of forming not only ideological and experiential communities, but also individualized and personalized practices. In other words, this issue seeks to demonstrate how religion can also be the product of the very things that it produces.

\section{Afro-American materialities}

Afro-American religions constitute an impressive medley of objects, materials, icons (Johnson, in this volume), substances, sounds (Wirtz, in this volume), colors (Kerestetzi, in this volume), and smells (Halloy, in this volume). And their practitioners tend to use these different elements without moderation. From Haitian Voodoo, Brazilian Candomblé or Umbanda, to Cuban Santería or Palo Monte, among many others, a large part of Afro-American ritual activity and interactions between initiates is dedicated to the making of religious artifacts (e.g. objects of power, amulets, magic potions, ritual garments). The technical moments involved in producing these objects are viewed as an essential step in the construction of religious affiliation and experience, primarily because they constitute privileged instances of interaction, learning, and exchange between the members of religious communities. Some authors, disputing the classical idea that ritual and faith are not subject to technical and material determinisms, have highlighted how ritual activity is inextricably linked to technical activity (Lemonnier 2005; Warnier 2009). Afro-American religions are a prime example of this: adherence to their symbolic universe is literally based on technical gestures and material transactions, to the extent that some followers, like those of Palo Monte, even define them as "material religions." 
In Santería, for example, the initiation rite is called "making the saint" (hacer santo), and in Candomblé "saint-making" (feitura de santo). These expressions refer to the fact that, during the initiation process, objects of power, which constitute physical incarnations of designated gods, are produced for the initiate. Indeed, within these religions, initiation cannot be envisaged independently of material production. ${ }^{3}$

When practitioners say that they "make a saint," this is meant literally. Religious objects are not mere representations of deities and spirits; they are veritable incarnations, imbued with personality, intent, feelings, and material needs. Whether we call them "spirited things" (Johnson 2014) or "god-objects" (Augé 1988), these sacred entities are the true recipients of a worshipper's prayers, not simply go-betweens for the divine. They are "living" gods, made animate by blood "transfusions" (Halloy 2015; Kerestetzi 2016), fed with food offerings, refreshed with drinks; these are gods who must be satisfied. In this way, the tension between the material and the intangible that these divine incarnations represent is redoubled by the tension between the animate and the inanimate.

This implicit theory of materiality, which blurs ontological lines, is not limited to religious artifacts and material products in the strictest sense; it also frames religious experience at its most visceral level. Thus, an initiate's body is "constructed" in the same way as an object, in the Afro-American sense, which means that the production of ritual subjectivity cannot be considered separately from material production. Indeed, the process of spiritual objectification mentioned above in reference to initiations in Santería and Candomblé (which also applies to the majority of related religions) is followed by a sort of objectification of the human body. For example, the head is viewed as something that is made to become the "seat" (asiento in Cuba) of a particular deity. In Brazil, "fazer cabeça" (making the head) is synonymous with "initiating" (Johnson 2002, p. 18). And, during these rites, the same actions, gestures, and substances are usually applied both to the newcomers' bodies and to their ritual objects (e.g. offerings of sacrificial blood, ritual cleansing), often one after the other, as if body and object were interchangeable. In this perspective, humans, things, and gods are ontological hybrids, somewhere between subject, object, and spirit.

In concrete terms, this situation provides for a rich repertoire of ritual actions: by objectifying religious agents, that is, treating the bodies of initiates and their gods as objects (in the Afro-American sense), practitioners can act on the body and interact with the spirits without resorting to abstract liturgical protocols; the materials and substances involved are of this world, they are mundane, familiar to the touch. Gods and humans are thus washed, polished, drawn, raised up, set down, sealed, opened; and all these manipulations are ritual acts in their own

3. For a similar analysis relating to Amerindian cosmologies, see Santos-Granero 2009. 
right. In Cuba, one must "lower" (bajar) Orula, the god of divination of the Cuban Ifá cult, and set him down on the ground to carry out certain delicate magical operations that require the full extent of his power. Objectifying one's religious agents serves to make them more approachable, and interacting with them more comfortable.

Therefore, we might discern in the act of production certain assumptions regarding the variability of Afro-American practices. Thus the most ancestral, the most powerful gods are fashioned by lowly devotees and for themselves. They are their personal gods, for their own exclusive use (see Capone 1999; Wirtz, in this volume). In this way, gods that are shared among the collective become "customized," tailored to specific people and to specific contexts. Be it the powerful lwa of Haitian Voodoo, the prestigious orichas of Santería, their counterparts in Candomblé and Xangô in Brazil, or the dead of Palo Monte in Cuba, these beings are made from scratch by the hands of their practitioners, and often reflect a singular vision of the religion in question, and of the idiosyncratic nature of each individual religious modality.

\section{Pre-constrained affordances}

Combining the question of religious sensoriality with that of materiality leads us naturally to examine the material "affordances" of religious spaces. The notion of affordance, part of the trend of the psychology of perception, notably in the work of James Gibson (1977), designates how the materiality or form of a given object or space dictates its usage (an open space may invite movement, a mug incites the user to hold it by the handle). Gibson viewed the physical environment as a "set of affordances." This approach has been widely criticized by culturalist researchers. David Howes (2009), for instance, highlighted the limitations of this cognitivist concept since, in his view, it does not take cultural factors into account. This issue seeks to bring together the two perspectives. In terms of its methodology, Arnaud Halloy's article is a good example of how to combine the analytical tools of the cognitive sciences with a precise ethnography of contextualized and culturally informed practices. The author proposes an "olfactographic" approach to religious practices, by examining how smell, ritual effectiveness, and religious emotion interconnect within Brazilian Xangô. His article shows how sensation and information come together in specific settings to create movement, knowledge, and religious memories.

In a linguistic approach, Kristina Wirtz's article, which examines the material production of the voice of the orichas in Santería, shows how the properties of the materials used ritualistically to instantiate this voice help to construct a communicative grammar with the other world. For example, the earthly nature of the orichas is transmitted auditorily through the percussive sound of the coconut husk used for divinatory purposes being thrown to the ground, and visually by 
their organic appearance. But the author reminds us that these properties do not automatically affect the way gods are perceived. The terrestrial aesthetic of these divination methods does not render the voice of the orichas terrestrial per se; rather it allows for a certain "balancing" of indexical transductions, that is, an equilibration of messages coming from different phono-sonic and indexical sources: insofar as the voice of the orichas is produced during ritual possessions and expressed through the bodies of the possessed, but also through the instruments of divination and invocation, such as bells, maracas, and sticks.

\section{Aesthetics}

How then do the morphology of sanctuaries and the aesthetic of god-objects impact practice itself? How do these create common ground (Hanks 2009) between participants, and how do they lead to the construction of an ideological community? For religious groups not only share the same religious aesthetic, but in fact grow and settle into "aesthetic formations" (Meyer 2009) or "sensational forms" (Meyer 2011) that create a shared community; here, "aesthetic formations" designate the material configurations involved in the embodiment, transmission, and even establishment of these communities, through the creation of unique "sensory orders" (Howes 1991). ${ }^{4}$ Religious experience is inextricably linked to sensory selection or "attentional filtering" (Schaeffer 2015, cited in Halloy, in this volume), which depends necessarily on the setting. Setting is key to the mechanisms of enchantment found in Afro-American religions, but this enchantment does not rest exclusively on beauty, even if in certain religions, such as Santería, the effectiveness of a ritual correlates with the beauty of the deities' avatars, even depends on it. The religious shaking found in Haitian or Cuban Voodoo, or in the Brazilian Egungun death cult of Itaparica, among others, is provoked by the anxiety and fear instilled by the enigmatic aesthetic of their dark, morbid, and bloody surroundings. Aesthetic, as we define it in this volume, should be seen not only as a product (of ideologies or traditions), but also as something that produces (ideologies and traditions). It is dynamic and constructive, in a way that is pragmatic, sensory, and profoundly somatic: the sensations aroused by the morphology of a religious place and its layout, the emotions conjured by its smell, the feelings evoked by its lighting - these elements are as necessary to the construction of religious experience and thought as are symbolism, mythology, and theology. This line of argument is developed in an analysis of multi-religious Cuban households (Kerestetzi, in this volume). These house-temples (casas-templos), which are at the heart of Afro-Cuban

4. The term "aesthetic" does not refer here to that things that are pleasing to the eye; rather it draws on its etymological root, from the Greek $\alpha \iota \sigma \theta \eta \tau \imath \kappa \eta$, which relates more to sensation ( $\alpha i \sigma \theta \eta \sigma \eta)$. 
rituality, often accommodate as many religions as there are family members (e.g. Santería, Palo Monte, Ifá, syncretic spiritism, Catholicism, or Protestantism). It should be noted that in Cuba, but also in Brazil or in Haiti, religious spaces are almost all domestic or private, sometimes the work of a single person, a ritual chief, or a handful of devotees. The article on multi-religious Cuban homes provides an analysis of the different aesthetic styles that can be found in a single house-temple, and the various logics that facilitate their coexistence under one roof. It shows that religious coexistence does not rely solely on processes of physical or symbolic distancing between different religious worlds, but also, even mostly, on processes of contact and interaction, in particular through the creation of aesthetic bridges; indeed, the morphological affinity of certain objects with artifacts belonging to other cults residing in the same household facilitates passage from one religious world to another. Here, we consider a dialog between aesthetic forms that open the doors of one cult to the space of another.

Afro-American ritual practices are quintessentially aesthetic, insofar as their sensory components - the decorums of their liturgical spaces, the design of ritual garments and religious objects - are ritual considerations in their own right, which practitioners take extremely seriously, and to which they dedicate much of their time and money. ${ }^{5}$ Afro-American spirits are seen as profoundly sensory beings. For their followers, they are "living beings" with whom they share the same sensory faculties: they hear, see, smell, taste, touch, and move. Moreover, contact with the other world is often seen in terms of interaction between human and divine sensoriality. In this regard, Arnaud Halloy's article shows us how the orichas' acute sense of smell and their taste for sacrificial meat opens up a world of praxis-based possibilities that condition religious emotion, at times even triggering ritual possessions. Paul C. Johnson's article demonstrates how the role played by the holy Slave Anastácia differs according to the aesthetic context in which she is featured. The author lays out how the praxeology that results from this icon's existence rests on a combination of her physical representation in a given setting and an imitation of her iconic properties: for example, when she is included in a Candomblé healing ritual, the "patient" may be required to observe a three-day silence in imitation of her muteness, symbolized by a muzzle. And when she appears life-sized in the Catholic Sanctuary of Anastácia, alongside the Archangel Michael and Saint George, the adepts are incited to kneel before her and pray. Ritual praxeology and the composition of the ritual worlds of Afro-American religions are therefore often structured around their practitioners' notions of divine senses.

5. For an analysis of the role of the senses in ethnography, see Santiago and Rougeon 2013. 
Human and divine sensibilities may sometimes come into conflict, leading to contradictory situations: in certain upscale Candomblé homes, for example, during ritual possession by warrior gods of nature, there may also be waiters present, circulating among the faithful offering champagne and appetizers. This situation exemplifies the seemingly paradoxical nature of religious materiality: on the one hand, ritual extravagance may be seen by religious devotees as a betrayal of their so-called "African" or "modest" values, tied to the romanticized setting of their original practices, while, on the other hand, it is theologically correct: the more one spends on one's gods, the more one's spiritual capital grows. Rather than seeing this situation as paradoxical or contradictory, this volume seeks in the aesthetic logic governing a religion a way to unlock a world of possible perceptions and applications - a motor for creativity.

\section{Spatial condensation}

Religious settings can be considered as areas of copresence between humans and deities, as well as points where real space and mythical and imagined places meet and intertwine - the residence of gods, or the sites of mythical events (see Hanks 2001; Stépanoff 2013). In Haitian Voodoo temples, for example, this spatial condensation takes material form in a post-the poteau-mitana veritable axis mundi that unites ritual space with the world of the spirits (Métraux 1959). Generally speaking, religious practice necessarily implies a transformation of the immediate setting. Various factors - linguistic, deictic, material, or technical - may indicate this fusion that is inevitably also temporal. In the rites of the Abakuá secret society, for example, certain ritual designs known as firmas are drawn in chalk to evoke, within the ceremonial space, the space-time of Abakuá's foundation myth (Bonhomme and Kerestetzi 2015).

For the practitioners themselves, spatial condensation implies their simultaneous presence in different spaces. This interrelation between their position in physical space and their imagined position should not be under-emphasized. Indeed, it is this very divergence, this artificial ubiquity, that allows the other worlds to manifest here on earth. Initiates of Afro-American religions are individuals who have come to embody various spaces. During Palo Monte initiations in Cuba, for example, initiates are said to "penetrate the world of the dead" and become fully fledged members of their society. Now that the dead recognize them, they follow them wherever they go, never losing sight of them. In other words, in Palo Monte, the world of the dead constitutes what Setha M. Low and Denise Lawrence-Zúñiga (2003) call an "embodied space." Initiation and ritual in general can also be considered as processes of embodying specific spatialities. In this way, Kristina Wirtz's article demonstrates how, thanks to these processes of spatial embodiment, practitioners of Santería are able to speak to their gods even outside the ritual frame intended to legitimize 
their interaction. And for Arnaud Halloy, the somatization of a ritual setting's olfactory experience triggers associated perceptions which, by their association with this place, become transportable. The author cites his own experience of Xangô liturgical places in Brazil, and the smell of sacrificial blood that he associated with them, to the extent that, in downtown Nice (in France), the smell of a butcher's shop was enough to plunge him straight back into the ritual setting. This embodiment breaches the confines of religious practice and carries it over into daily life.

\section{Topological bricolages}

The ritual space of Afro-American religions is one of copresence between humans and spirits, but also between very distinct physical spaces and temporalities, both religious in nature and not: the romanticized Africa of their origins that remains central to the development of Afro-American religious identities; the space-time of myths and cosmogonies; the places currently inhabited by spirits and gods; and even the space of the history of South America and its indigenous populations - all of these represent geometric coordinates for the religious present. Stephan Palmié (2002) demonstrates, for example, how the historical representations of enslaved Africans - seen as the founders of modern-day religions - and their lives on the plantations not only structure religious imagination, but actually turn into ritual components in their own right, and even into material objects. David Brown (2003) describes how the space of initiations in Santería condenses not only mythical times, but also representations surrounding royalty and the armies of the Spanish colonizers. As Aisha Beliso-De Jesús writes, in regard to this Cuban example, "copresences are comfortable with irreconcilability" (2015, p. 10). Multi-religious households in Cuba represent an extreme case-study of how this spatial organization functions (Kerestetzi, in this volume). These places constitute a spectacular synthesis of different and often contradictory spatialities and temporalities that must be reconciled within the limited confines of a single house. Inside these homes, family dynamics and the tastes of the inhabitants acquire a spatial form themselves that becomes an essential part of these religious practices.

This dynamic animating the day-to-day interactions between different practices invites us to reflect on the modalities of Afro-American syncretism. Generally speaking, Afro-American religions are the product of contact between different cultures, and as a result are deeply syncretic in nature. In Cuba, Brazil, and elsewhere, local religions find themselves in a constant exchange of symbols, religious procedures, and even gods. The theme of syncretism therefore became a natural point of departure in the anthropological study of these religious practices, and was mainly approached through historical and sociological perspectives (e.g. Rodrigues 1900; Herskovits 1941; Bastide 1970; Ortiz 2001 
[1906]) - a logical consequence given that Afro-American religions emerged from the historical fact of the colonization of the New World, and the slave trade. This issue pursues this line of thinking, while also seeking a fresh methodological approach, by exploring Afro-American syncretism as a (perhaps material) process of conciliation between different presences, different localities, and different aesthetics. Syncretism thus becomes a topological question, one of connecting or separating different religious worlds. This approach "secularizes" the concept, insofar as not all the spaces and locations that make up the religious are necessarily themselves religious in nature; what we might describe as hybrid syncretism. By extension, we find that the case of Cuban households demonstrates how certain processes pertaining to Afro-Cuban syncretism operate according to a logic of practical necessity. Within these settings, there exists what we might call an ad hoc syncretism that draws on all available material affordances that the environment provides. Real-time practical considerations, needs, and desires also come together and transform into ritual components, thereby constraining syncretic modalities to the point of eclipsing religious differences.

This collection of articles also shows how history interacts with the material and aesthetic worlds of these religions: how, for example, icons and ritual objects act on the imagination and serve to create unique representations of the past. Kristina Wirtz's article, for instance, explores in detail how the voices of the orichas index different ritual space-times and different genealogical-historical trajectories simultaneously. Paul C. Johnson, meanwhile, highlights the creative vitality of "Africanized" and "indigenized" versions of Catholicism, demonstrating how the historical trajectory of a Brazilian saint cannot be considered independently of her materiality and her emplacement, which both serve to restructure the different representations attached to her in Brazil.

\section{The situated body}

Our proposal here does not seek to separate the different categories of perception or sensitivity, or to prescribe any relations of causality or primacy between them; the sensoriality, morphology, and layout of a particular place confine the body and its movements, its perceptions, its affects. One cannot truly say if a movement provokes a sensation, or vice versa; if a sensation provokes an emotion, or vice versa. In religious settings, sensation, emotion, mood, and even thought come together to form an interconnecting system.

Space creates action (Rapoport 1982). Whether domestic, ritual, or digital, space can be viewed as a framework in which actions repeat themselves. Spatial morphology regulates the scope and orientation of our movements. A linear arrangement is more open to action than a central, more "fixed" one (Baker 1994 [1985], p. 9). Using a mobile device encourages us to stand still while the fingers 
and eyes move hyperactively. The layout of a space may thus provoke certain actions, as well as specific sensorimotor patterns that constrain the body, what it feels and experiences. The positioning of a religious object can also determine ritual form itself. Placing ritual objects in the most commonly occupied parts of a multi-religious Cuban household increases the chances for interaction between its inhabitants and their gods, as well as the number of specifically ritual acts. We might call this induced, or opportunistic, rituality: copresence alone is enough to spur action. In contrast, a more peripheral placement, or one with minimal interactional value, may limit ritual practice and foment inactivity.

This perspective opens the door to a situated approach to the body, and to the processes of embodiment, which challenges its ontological autonomy. It is no longer about a question of referring to the ritual body and its various states per se, but rather as part of a larger ecological relation: a body in space and in context. And yet we can also view space as an externalized body, like a mirror being held up to it, reflecting its configuration, its sensations and movements (Kerestetzi 2017). This is, moreover, what Arnaud Halloy (in this volume) designates the "materiality of perception." For this author, religious sensations and perceptions are not the result of interaction between an individual and an object alone, but rather of an individual and a context, since they depend on a set of bodily processes that only occur in a specific frame of action. In a strictly synesthetic approach, the author explains how the axé, a sort of "Afro-American mana" (see Holbraad 2007) that endows earthly beings with their vital and spiritual power, acquires its own smell via these situated bodily processes, but also a taste and a texture. Kristina Wirtz also shows how communication with the other world in Santería is a matter of equivalences and heteroglossic transductions that bring the sensoriality of a setting into play, in a marriage of iconicity and indexicality: the voice of the orichas is not just heard; it is seen, felt, and tasted, too.

In summary, the articles in this issue show that the power of a religious setting is not only praxeological or representational; it also involves what David Morgan (2010, p. 58) described as the contagion of emotions (citing Thagard 2006 and Lundquist and Dimberg 1995). The term was originally used to designate a sort of unconscious imitation of the natural states of other people. We borrow it here to describe the potential for emotional contamination that the spirit of a religious place holds.

Acknowledgments - I thank greatly Grégory Fornal, Paul C. Johnson and Arnaud Halloy for their wise comments and encouragement, and Dominic Horsfall for his beautiful translation. 


\section{References cited}

AtKInSON Jane M.

1989 The art and politics of Wana Shamanship, University of California Press Berkley, California.

Augé Marc

1988 Le dieu objet, Flammarion, Paris.

BAKER Geoffrey $\mathrm{H}$.

1994 [1985] Le Corbusier. Analisis de la forma, Editorial Gustavo Gili, Barcelona.

BASTIDE Roger

1970 "Mémoire collective et sociologie du bricolage", L'Année sociologique, 21, p. $65-108$.

Beliso-De Jesús Aisha M.

2015 Electric santería. Racial and sexual assemblages of transnational religion, Columbia University Press, New York.

BERgSON Henri

1889 Essai sur les données immédiates de la conscience, F. Alcan, Paris.

Bonhomme Julien and Kerestetzi Katerina

2015 "Les signatures des dieux. Graphisme et action rituelle dans les religions afro-cubaines", Gradhiva, 22, p. 74-105.

BRown David H.

2003 Santeria enthroned: art, ritual, and innovation in an Afro-Cuban religion, University of Chicago Press, Chicago/London.

BRown Karen McCarthy

1996 “Altars happen”, African Arts, 29 (2), p. 67

CAPONE Stefania

1999 La Quête de l'Afrique dans le Candomblé : pouvoir et tradition au Brésil, Karthala, Paris.

Certeau Michel de

1980 L'Invention du quotidien 1, Gallimard, Paris.

CoHen Anouk and Damien MotTIER

2016 "Pour une anthropologie des matérialités religieuses", Archives de sciences sociales des religions, 174, p. 349-368.

Cohen Anouk, Katerina Kerestetzi and Damien Mottier

2017 "Introduction. Sensorialité religieuse : sens, matérialités, expériences", Gradhiva, 26, p. 4-21.

Cummins Thomas B.F. and Joanne RAPPAPORT

1998 "The reconfiguration of civic and sacred spaces. Architecture, image and writing in the Colonial Northern Andes", Latin American Literary Review, 26 (52), p. 174-200. 
EsPirito SANTo Diana and Nico TASsi (eds.)

2013 Making spirits. Materiality and transcendence in contemporary religions, I. B. Tauris, London.

Gell Alfred

1998 Art and agency: an anthropological theory, Oxford University Press, New York, Oxford.

GiBson James J.

1977 "The Theory of Affordances", in Robert Shaw and John Bransford (eds.), Perceiving, acting, and knowing, toward an ecological psychology, Halsted Press Division, Wiley, New York.

GofFman Erving

1991 Les cadres de l'expérience, éditions de Minuit, Paris.

HaLl Edward Twitchell

1966 The Hidden Dimension, Doubleday, New York.

HALloy Arnaud

2015 Divinités incarnées : l'apprentissage de la possession dans un culte afrobrésilien, Pétra, Paris.

Hanks F. William

2001 "Copresence and alterity in Maya ritual practice", in William F. Hanks (ed.), Intertexts. Writings on language, utterance, and context, Rowman \& Littlefield, Lanham, p. 221-248.

2009 “Comment établir un terrain d'entente dans un rituel ?", Cahiers d'anthropologie sociale/Les paroles en actes, 5, p. 87-113.

Herskovits Melville J.

1941 The myth of the negro past, Harper \& Brothers Publishers, New York/London.

HiRsCHKIND Charles

2006 The ethical soundscape. Cassette sermons and islamic counterpublics, University Press, New York/Columbia.

HOLBRAAD Martin

2007 "The power of powder: multiplicity and motion in the divinatory cosmology of Cuban Ifá (or mana, again)", in Amiria Henare, Martin Holbraad and Sari Wastell (eds.), Thinking through things. Theorising artefacts ethnographically, Routledge, London/New York, p. 189-225.

Howes David

1991 The varieties of sensory experience. A sourcebook in the Anthropology of the senses, University of Toronto Press, Toronto.

Howes David (ed.)

2009 The sixth sense reader, Berg, Oxford/New York.

Hutchins Edwin

2001 "Distributed cognition", in The International Encyclopedia of the Social and Behavioral Sciences, p. 2068-2072. 
The spirit of a place: materiality, spatiality, and feeling in Afro-American religions

Johnson Paul Christopher

2002 Secrets, Gossip, and Gods: the transformation of Brazilian Candomblé, Oxford University Press, Oxford.

Johnson Paul Christopher (ed.)

2014 Spirited things. The work of "possession" in Afro-Atlantic religions, The University of Chicago Press, Chicago.

KeANE Webb

2008 "The evidence of the senses and the materiality of religion", Journal of the Royal Anthropological Institute, 14, p. 110-127.

Kerestetzi Katerina

2016 Vivre avec les morts à Cuba : réinvention et transmission religieuse dans le palo monte afro-cubain, Karthala (Religions contemporaines), Paris.

2017 "Architectures divines : espace et kinesthésie dans le palo monte afro-cubain", Gradhiva, 26, p. 100-133.

LATOUR Bruno

2007 "Sociologie sans objet? Remarques sur l'interobjectivité", in Octave Debary and Laurier Turgeon (eds.), Objets \& Mémoires, éditions de la Maison des Sciences de l'Homme, Paris/Presses de l'université Laval, Québec, p. 37-59.

LEMONNIER Pierre

2005 "Mythiques chaînes opératoires", Techniques et cultures, 43-44, p. 25-43.

2012 Mundane objects. Materiality and non-verbal communication, Left Coast Press, Walnut Creek (CA).

Low Setha M. and Denise Lawrence-ZúÑIga

2003 "Locating culture", in Setha M. Low and Denise Lawrence-Zúñiga (eds.), The anthropology of place and space: locating culture, Blackwell Publishers, Oxford, p. 1-49.

LUNDQUIST Lars-Olov and Ulf DIMBERG

1995 "Facial expressions are contagious", Journal of Psychophysiology, 9, p. 203-211.

MÉtraux Alfred

1959 Le vaudou haïtien, Gallimard, Paris.

Meyer Birgit

2011 "Mediation and immediacy: sensational forms, semiotic ideologies and the question of the medium", Social Antrhopology, 19 (1), p. 29-39.

MEYer Birgit (ed.)

2009 Aesthetic Formations. Media, Religion and the Senses, Palgrave, New York.

Morgan David

2010 Religion and Material Culture: the Matter of Belief, Routledge, Londres, New York.

2013 "Religion and media: a critical review of recent developments", Critical research on religion, 1 (3), p. 347-356. 
ORTIZ Fernando

2001 [1906] Los negros brujos: apuntes para un estudio de etnología criminal, Ciencias Sociales, La Havana.

PAlmié Stephan

2002 Wizards \& Scientists: explorations in Afro-Cuban modernity \& tradition, Duke University Press, Durham, London.

PINNEY Christopher

2004 Photos of the Gods. The printed image and political struggle in India, Reaktion, London.

Porteous John Douglas

1990 Landscapes of the mind, words of sense and metaphor, University of Toronto Press, Toronto.

Promey Sally (ed.)

2014 Sensational religion. Sensory cultures in material practice, Yale University Press, New Haven.

RAPOPORT Amos

1982 The meaning of the built environment. A nonverbal communication approach, University of Arizona Press, Arizona.

RichaRdSON Miles

2003 "Being-in-the-market versus being-in-the-plaza: material culture and the construction of social reality in Spanish America", in Setha M. Low and Denise Lawrence-Zúñiga (eds.), The anthropology of place and space: locating culture, Blackwell Publishers, Oxford, p. 74-92.

RichMAN Karen

2005 Migration and Vodou (New World Diasporas), University Press of Florida, Florida.

RoDrigues Nina Reimundo

1900 O animismo fetichista dos negros baianos, Reis \& Co, Salvador de Bahia.

Rowlands Michael

2007 "The sound of witchcraft: noise as mediation in religious transmission", in David Berliner and Ramón Sarró (eds.), Learning religion: anthropological approaches, Berghagn Books, New York, Oxford, p. 191-208.

Santiago Jorge P. and Marina Rougeon

2013 Pratiques religieuses afro-américaines. Terrains et expériences sensibles, Academia, Louvain-La-Neuve/L'Harmattan, Paris.

SAntos-Grannero Fernando (ed.)

2009 The occult life of things. Native Amazonian theories of materiality and personhood, The University of Arizona Press, Tucson.

SEgAud Marion

2012 Anthropologie de l'espace. Habiter, fonder, distribuer, transformer, Armand Colin, Paris. 
The spirit of a place: materiality, spatiality, and feeling in Afro-American religions

SMiтH Jonathan

1987 To take place: toward theory in ritual, Chicago University Press, Chicago.

STÉPANOFF Charles

2013 "Dessins chamaniques et espace virtuel dans le chamanisme khakasse", Gradhiva, 17, p. 144-169.

STOLOW Jeremy

2012 Deus in Machina. Religion, technology, and the things in between, Fordham University Press, New York.

Thagard Paul

2006 Hot thought. Mechanisms and applications of emotional cognition, Bradford Book/MIT Press, Cambridge (MA).

WARNIER Jean-Pierre

2009 Régner au Cameroun : le roi-pot, Karthala, Paris. 
